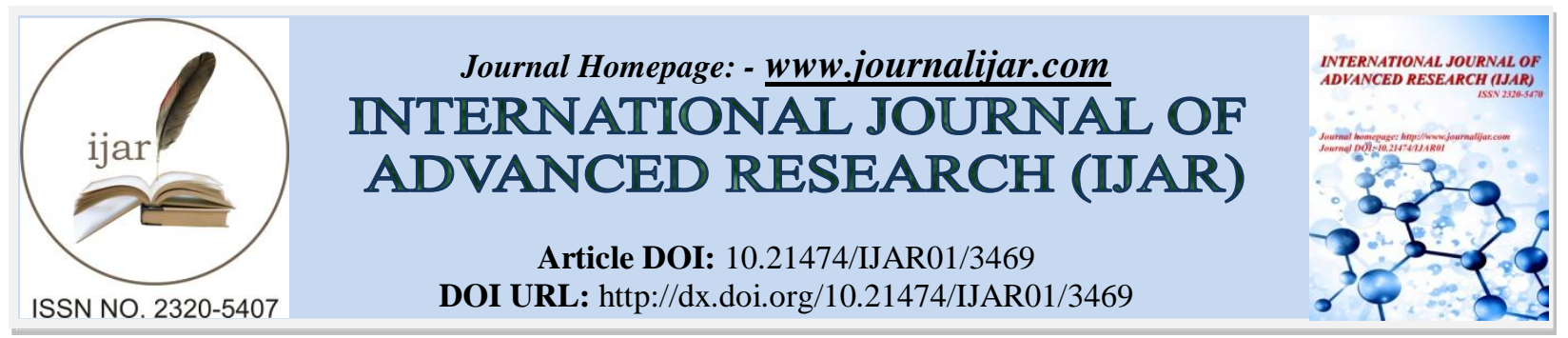

RESEARCH ARTICLE

\title{
EXTRAOCULAR INJURIES CAUSED BY PELLET GUNS. DOES IT SEAL THE LESS LETHAL DEBATE? THE KASHMIR EXPERIENCE.
}

Dr. Zahida Akhter M.S ${ }^{1}$, Dr. Showkat Majeed Kakroo ${ }^{2}$ and Dr. Shabir Ahmed Dhar ${ }^{3}$.

1. Lecturer, DEPTT OF GENERAL SURGERY, Skims Medical College Srinagar.

2. Surgeon specialist deptt of health Kashmir,

3. Deptt of orthopedics skims medical college Srinagar

\section{Manuscript Info}

Manuscript History

Received: 30 December 2016

Final Accepted: 17 January 2017

Published: February 2017

\section{Abstract}

The search for a non-lethal method of crowd control goes on. A lot of literature in recent years has pointed to the fact that projectile based munitions should be reclassified as lethal weapons while quoting supporting facts and figures of mortality and morbidity caused by these weapons. In recent times, a new method of crowd control in the form of a pellet gun has been used by the authorities in Kashmir. The wide range and severity of injuries to extra ocular tissues caused by the pellets from this gun further buttresses the argument that projectile based munitions in all forms inflict severe injuries to all tissues. It is also important in the present day for all surgeons to be well versed with the challenges concerning the management of these injuries. The surgical skills need to be sharpened while continuing to send out a call for milder methods of crowd control.

Copy Right, IJAR, 2017,. All rights reserved.

\section{Introduction:-}

The Lone Ranger never killed a bad man. In 22 years of fighting for justice (on radio and television), he always aimed at the outlaw's gun. In doing so, he not only defeated his enemies, but he won over the hearts and loyalties of millions of kids [1].

The management of public dissent is a challenge for governments the world over. This dissent is especially difficult when it is shown by large crowds. Several methods of crowd control have been developed by agencies the world over. The intent of these weapons is to subdue or incapacitate violent or dangerous suspects without causing serious harm or death. Commonly used less lethal weapons include chemical irritant agents, explosive distraction devices, kinetic impact munitions, and electrical incapacitation devices [2]

Kinetic impact munitions are basically projectile based weapons which are fired to cause superficial injuries to the protestor as there is transfer of kinetic energy to the body. However, the amount of kinetic energy transferred to the human body by these munitions is variable depending upon the size of the munitions as well as the distance from which it is fired. 
Kashmir has provided a rather large arena for the use of the pump action projectile pellet gun this year. While as most of the reportage has focused on eye injuries, a number of extra ocular injuries flooded the hospitals during the first month of the protests.

This report outlines the range of extra ocular injuries witnessed by our hospital, the management problems and the residual issues faced by these patients. It perhaps also provides significant ballast to the argument that the pellet gun should be classified as a lethal weapon.

\section{Material and Methods:-}

The valley of Kashmir witnessed large scale protests and protesting crowds from July $8^{\text {th }} 2016$. The authorities used the pump action pellet gun on a very large scale to control the crowds with over 3 thousand shots fired. This caused injuries to many people. Our hospital also received a large number of patients injured by these projectiles. While as an unprecedented number of patients were hit in the eyes, we focused on the extra ocular injuries that we treated in the first month of the unrest. We report on 30 patients with extra ocular injuries who needed admission for management during the first month. Patients who could be treated on an outdoor basis were excluded from the study.

\section{Results Observations:-}

Most of the superficial wounds were cleaned with antiseptics only. This was followed by regular dressings. In cases with larger wounds and multiple pellets lodged enmasse, the skin was debrided to the area where it started bleeding. Tendon injuries were debrided and reconstructed, but significant stiffness ensued due to underlying comminuted phalangeal fractures in two patients.

Three cases presented late with primary wound management done at a local level. Infection of the wound was the cause for referral as the patients had tried to remove the pellets themselves fearing police arrest or reprisals in the hospitals. All cases were treated with debridement of the wound followed by washes.

In two cases some pellets were present within the joints. Both bullets were retrieved and repeated joint washes were given.

A significant number of wounds were small but a large number sustained by being shot at close range caused significant damage at the entry site. This can be imagined due to 600 pellets striking simultaneously. Such wounds were surrounded by skin splits which were debrided.

Most of the larger wounds were managed in the operating theatre by longitudinal incisions in the fascia and skin to relieve the hematoma and remove the debris and the pellets within a zone of safety.

The muscle was debrided along the time-honored concept of color, consistency, contractility and circulation. The area was allowed to drain in cases with extensive damage. The primary wound tract, otherwise known as the permanent cavity was cleaned and washed. The contusion zone of muscle adjacent to the track created by the pellet mass was washed. The concussion zone formed by the shock waves produced during cavitation which causes damage distant from the immediate track area was not explored according to the principles of debridement.

We also received many patients who had sustained pellet injuries to chest and abdomen. Most of these patients had superficial injuries. Many of the pellets were superficial and were removed by the patients themselves and some pallets got spontaneously extruded from the skin. In these patients local cleaning with antiseptic solution was done. Some of the pellets were very superficial and were removed at the time of examination only. Some of our patients had got serious injuries to chest and abdomen. Nine patients had sustained pallet injuries to chest. Out of nine patients, intercostal tube drainage (ICTD) was put in 5 patients (two right ICTD and 3 left ICTD).Rest of the patients were managed conservatively. 
Table 1:-

\begin{tabular}{|c|c|c|c|c|c|}
\hline S.no & Age(years) & Sex & Type of injury & Radiology & Procedure \\
\hline 1 & 25 & male & Pellet Right side chest & normal & $\begin{array}{l}\text { Debridement with } \\
\text { primary closure }\end{array}$ \\
\hline 2 & 23 & male & $\begin{array}{l}\text { Pellet injury to anterior } \\
\text { right lower chest with } \\
\text { small exit wound on } \\
\text { posterior aspect }\end{array}$ & $\begin{array}{l}\text { Contusion right } \\
\text { lower lobe of lung. }\end{array}$ & $\begin{array}{l}\text { Right ICT drainage } \\
\text { with debridement } \\
\text { and primary closure } \\
\text { of wound. }\end{array}$ \\
\hline 3 & 17 & male & $\begin{array}{l}\text { Pellet injury left side of } \\
\text { the chest }\end{array}$ & Left hemothorax & Left ICTD \\
\hline 4 & 17 & MALE & $\begin{array}{l}\text { Pellet injury left side of } \\
\text { chest }\end{array}$ & Left pneumothorax & Left ICTD \\
\hline 5 & 20 & MALE & $\begin{array}{l}\text { Pellet injury right side } \\
\text { of chest }\end{array}$ & $\begin{array}{ll}\text { Right } & \text { side } \\
\text { hemothorax } & \\
\end{array}$ & Right ICTD \\
\hline 6 & 18 & male & Pellet all over chest & normal & $\begin{array}{l}\text { Local cleaning with } \\
\text { antiseptic solution }\end{array}$ \\
\hline 7 & 24 & male & $\begin{array}{l}\text { Pellet injury chest all } \\
\text { over }\end{array}$ & normal & $\begin{array}{l}\text { Local cleaning with } \\
\text { antiseptic solution }\end{array}$ \\
\hline 8 & 18 & male & $\begin{array}{l}\text { Pellet injury left side of } \\
\text { chest }\end{array}$ & normal & $\begin{array}{l}\text { Local cleaning with } \\
\text { antiseptic solution }\end{array}$ \\
\hline 9 & 24 & male & $\begin{array}{l}\begin{array}{l}\text { Pellet injury left side } \\
\text { chest }\end{array} \\
\end{array}$ & Left pneumothorax & Left ICTD \\
\hline
\end{tabular}

We also received patients who had sustained pellet injuries to abdomen. Some of the injuries were superficial which were managed by local cleaning with antiseptic solution and superficial pellet removal while as some patients had received serious intra-abdominal injuries requiring exploration. In three patients exploratory laparotomy with resection/primary repair of the perforation and covering stoma was done. Rests of the patients were managed conservatively.

(Table 2:-

\begin{tabular}{|c|c|c|c|c|c|}
\hline $\mathrm{S} \mathrm{No}$ & Age(Years) & Sex & Type of Injury & Radiology & Procedure \\
\hline 1 & 25 & male & $\begin{array}{l}\text { Pellet injury } \\
\text { abdomen }\end{array}$ & $\begin{array}{l}\text { Multiple perforation } \\
\text { over right half of } \\
\text { transverse colon } \\
\text { with grade I liver } \\
\text { laceration }\end{array}$ & $\begin{array}{l}\text { Exploratory Laparotomy with transverse } \\
\text { colectomy with end to end anastomosis } \\
\text { with covering ileostomy }\end{array}$ \\
\hline 2 & 23 & Male & $\begin{array}{l}\text { Pellet injury } \\
\text { abdomen }\end{array}$ & $\begin{array}{l}\text { Grade I Laceration } \\
\text { upper pole of right } \\
\text { kidney, multiple foci } \\
\text { of air in retro } \\
\text { peritoneum. 11th rib } \\
\text { fracture with no } \\
\text { obvious gut injury. }\end{array}$ & $\begin{array}{l}\text { Managed conservatively for abdominal } \\
\text { injuries. }\end{array}$ \\
\hline 3 & 30 & Male & $\begin{array}{l}\text { Pellet injury } \\
\text { abdomen }\end{array}$ & Hemoperitoneum & $\begin{array}{l}\text { Exploratory laparotomy with primary } \\
\text { repair sigmoid colon perforation with } \\
\text { transverse loop colostomy. }\end{array}$ \\
\hline 4 & 17 & Male & $\begin{array}{l}\text { Pellet injury } \\
\text { abdomen }\end{array}$ & normal & Conservative management \\
\hline 5 & 20 & Male & $\begin{array}{l}\text { Pellet injury } \\
\text { abdomen }\end{array}$ & Hemoperitonium & $\begin{array}{l}\text { Exploratory laparotomy with primary } \\
\text { closure of gut perforation. }\end{array}$ \\
\hline 6 & 24 & Male & $\begin{array}{l}\text { Pellet injury } \\
\text { abdomen }\end{array}$ & normal & Conservative management \\
\hline
\end{tabular}

We used second generation cephalosporins and aminoglycosides in all cases at the outset before obtaining culture sensitivity reports. 


\begin{tabular}{|c|c|c|c|c|c|}
\hline S.No & $\begin{array}{l}\text { Age( } \\
\text { yrs) }\end{array}$ & Sex & Injury & Exam & Procedure \\
\hline 01 & 25 & Male & $\begin{array}{l}\text { Pellet injury with fracture BB } \\
\text { Right Leg (open type iii B) }\end{array}$ & $\begin{array}{l}\text { Right Leg lacerated wound } \\
\text { with loss of skin } \\
\text { approximately } 6 \times 12 \mathrm{~cm} \text { on } \\
\text { anterior aspect of distal leg } \\
\text { plus another lacerated } \\
\text { wound with loss of skin } \\
\text { approximately } 4 \times 8 \mathrm{~cm} \text { on } \\
\text { anterior aspect of leg. } \\
\text { Tendon junction ok, DNVS } \\
\text { ok }\end{array}$ & $\begin{array}{l}\text { CR done and external } \\
\text { fixate applied using } \\
\text { two connecting rods } \\
\text { (12 clamps) }\end{array}$ \\
\hline 02 & 24 & Male & $\begin{array}{l}\text { Pellet injury left thigh with } \\
\text { fracture neck of femur with CCS } \\
\text { in-situ fresh fracture } \\
\text { subtrochantric left femur }\end{array}$ & & $\begin{array}{l}\text { Conservative } \\
\text { management to be } \\
\text { done for two weeks }\end{array}$ \\
\hline 03 & 28 & Male & $\begin{array}{l}\text { Pellet injury right gluteal region } \\
\text { upper and lower back }\end{array}$ & $\begin{array}{l}\text { Lacerated wound } 3 \times 2 \mathrm{~cm} \\
\text { right gluteal region } \\
\text { multiple pellet injuries on } \\
\text { upper and lower back }\end{array}$ & $\begin{array}{lr}\text { Debridement of } \\
\text { wound under LA } \\
\text { managed } \\
\text { conservatively }\end{array}$ \\
\hline 04 & 16 & Male & $\begin{array}{l}\text { Injury fracture shaft of femur } \\
\text { right side. }\end{array}$ & & $\begin{array}{l}\text { CRIF with ILIMN } \\
10 \times 40 \mathrm{~mm}\end{array}$ \\
\hline 05 & 35 & Male & Bilateral sub condylar fracture & & $\begin{array}{l}\text { ORIF with DFL } \\
\text { palate for fracture } \\
\text { femur rt. And fracture } \\
\text { tibia rt. }\end{array}$ \\
\hline 06 & 19 & Male & $\begin{array}{l}\text { Pellet injury right Thigh (open } \\
\text { type iii B with fracture shut of } \\
\text { femur }\end{array}$ & & OR with EF \\
\hline 07 & 24 & Male & $\begin{array}{l}\text { Pellet with fracture neck of } \\
\text { femur left }\end{array}$ & & $\begin{array}{l}\text { CCS fixation left plus } \\
\text { VAC }\end{array}$ \\
\hline 08 & 25 & Male & $\begin{array}{l}\text { Fracture both bones right Leg } \\
\text { with Achilles tendon injury } \\
\text { (compound type iii) }\end{array}$ & & $\begin{array}{l}\text { External fixation for } \\
\text { fracture tibia with } \\
\text { HLA tender repair }\end{array}$ \\
\hline 09 & 20 & Male & $\begin{array}{l}\text { Fracture shaft of femur right } \\
\text { compound type iii }\end{array}$ & & $\begin{array}{lcc}\text { External fixation } & \text { of } \\
\text { fracture } & \text { shaft } & \text { of } \\
\text { femur } & & \\
\end{array}$ \\
\hline 10 & 21 & Male & $\begin{array}{l}\text { Injury right shoulder with } \\
\text { fracture distal humerus right } \\
\text { with fracture both bones } \\
\text { proximal Forearm right floating } \\
\text { elbow compound type iii B }\end{array}$ & & $\begin{array}{l}\text { External fixation for } \\
\text { right shoulder }\end{array}$ \\
\hline 11 & 40 & Female & $\begin{array}{l}\text { Pellet injury both lower limbs } \\
\text { with committed fracture proxy. } \\
\text { Tibia left. (open type iii fracture } \\
\text { medial tibia right Open type ii) }\end{array}$ & & $\begin{array}{l}\text { E.F and debridement } \\
\text { left leg }\end{array}$ \\
\hline 12 & 16 & Male & $\begin{array}{l}\text { Pellet injury right leg with } \\
\text { fracture medial femoral condyle } \\
\text { with EF in situ with } \\
\text { RVSG+STSG }\end{array}$ & & \\
\hline
\end{tabular}

Out of 12 patients 11 were male 1 was female.11 patients had lower limb involvement while as 1 patient had upper limb involvement. 6 patients were managed by external fixation, three patients had internal fixation, 3 patients were managed without fixations. 
We continue to observe follow up patients. Several cases report discomfort due to the subcutaneous location of the pellets which has made some postures painful. A large number of patients are also reporting back with draining sinuses from several pellet sites. As the follow up is short, it is difficult to guess how many pellets may need to be removed over a prolonged period before these patients return to normal.

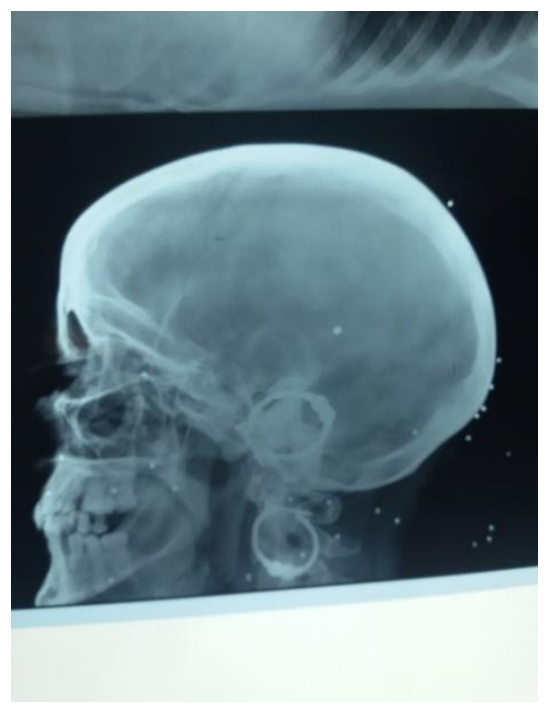

Fig: X ray skull showing multiple pellets

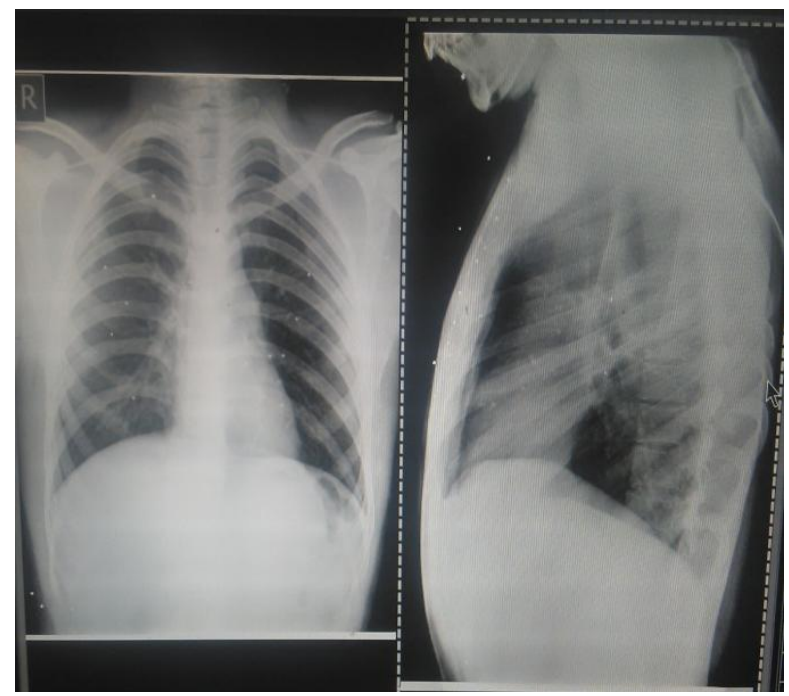

Fig:CXR PA view and lateral view with pellets every where 


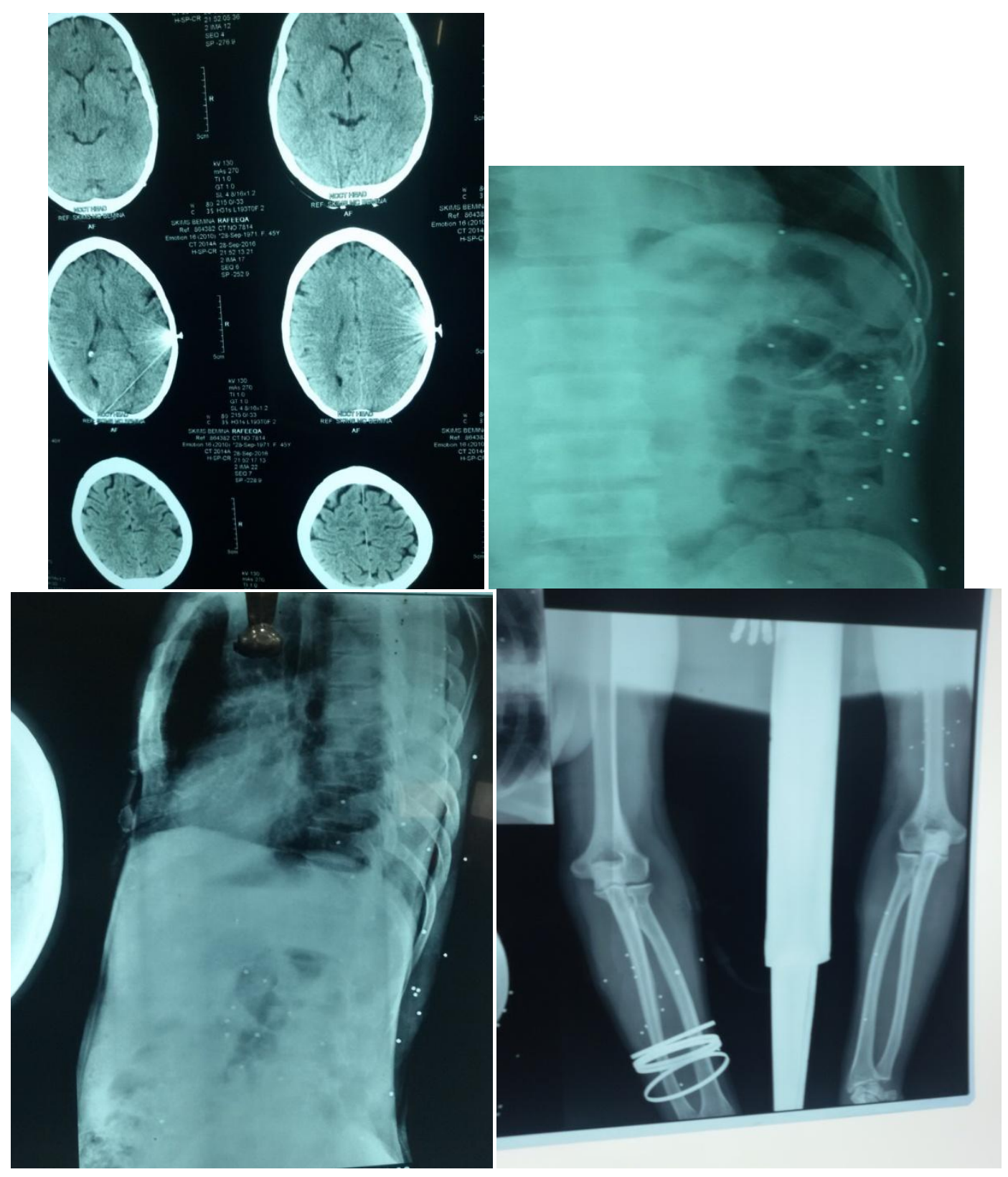

Fig: NCCT head and radiographs showing how deep pellets can reach and how much injury they can inflict 

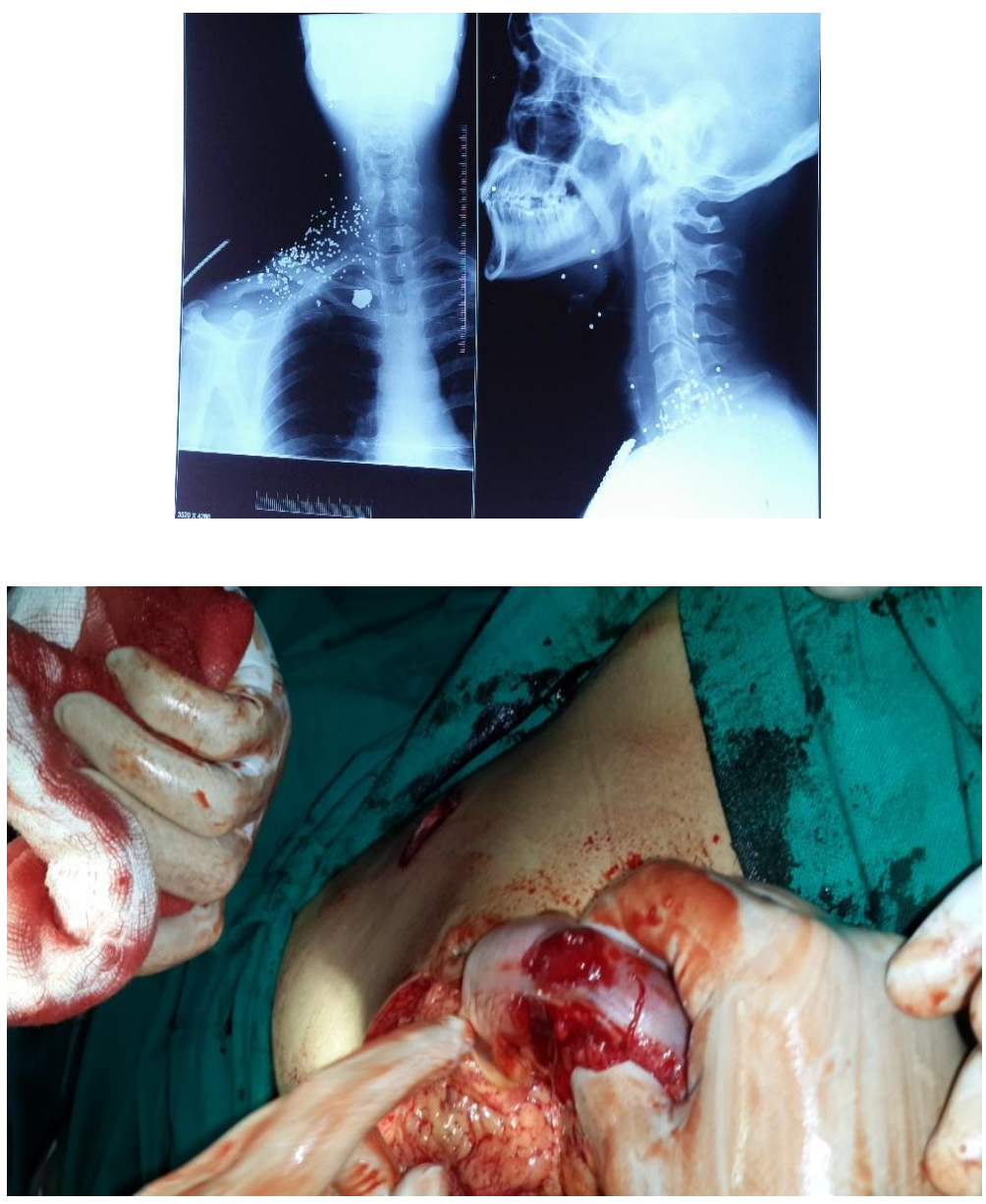

Fig:- intra operative picture of gut perforation ( pallet injury to sigmoid colon)

\section{Discussion:-}

Many law enforcement and military agencies are adopting so-called "less-lethal weapons" that are also called "nonlethal weapons," "sub lethal weapons," or "less-than-lethal weapons." [2].

In simple terms Non-Lethal/Less lethal incapacitation means 'to render a suspect incapable of action by means of force which is highly unlikely to cause death or serious injury when properly applied'[3]

While less lethal weapons are significantly safer than traditional firearms, no weapon can be entirely non-lethal and no weapon can be made entirely safe. Medical providers may treat subjects exposed to less lethal weapons and should presume injury until proven otherwise. They should be familiar with less lethal weapons' actions, effects, and typical injury profiles [4]

Projectiles deform upon impact to provide maximal surface area and a reduced likelihood of penetrating injury. However, skin penetration does occasionally occur [5].

However, intra abdominal, intra thoracic, ocular, intracranial, and extremity penetrations of intact projectiles have all been reported. In addition, bean bag type projectiles have been reported to rupture upon impact, releasing their numerous small metallic pellets which then produce penetrating injuries [4].

Less-lethal weapons "were originally intended as a de-escalation tool, as a substitute for deadly force. But in many cases it became an add-on, substituting for a less serious form of physical force."[6]The manufacturer of pellet guns, used against protesters by armed forces in Kashmir, said they are generally used for hunting. No tests have been 
conducted regarding their effect on the human body [7].technically called 12 Bore Pump Action guns, can contain shots of various sizes ranging from 'BB' to 9 , with $\mathrm{BB}$ being the largest and 9 number the lowest. The state police only make use of number 9 pellets to deal with the protestors [7].

The pellet gun injury raises several challenges for the treating doctor. These challenges are enumerated below

1. Lack of any literature as a guide for the management of these injuries.

2. Presence of hundreds of small projectiles spread over a rather large area involving bone, nerve, vessel, and muscle simultaneously in a large percentage of cases.

3. High incidence of missed injuries due to a large number and spread of the projectiles.

4. Difference between the types of injury caused by the projectiles fired point blank versus shots fired from a distance.

5. To avoid being arrested, several protestors had removed the superficial pellets at home with knives and razors creating additional wounds. These cases presented late and with infected wounds.

In all cases local wound care consists of superficial irrigation and careful cleansing followed by dressing. The tracks of the individual pellets are allowed to heal and only dressed regularly. In cases with large entry wounds caused by point blank shots, the wound track should be cleaned and pellets removed along with the detritus. In spite of significant debridement, some peripheral pellets remain. The margins of the entrance wounds should be excised and the missile tract thoroughly irrigated. A wide debridement of devitalized tissue is to be performed and foreign bodies removed. The patients with larger wounds should be returned to the operating room every $48-72 \mathrm{~h}$ for serial debridement. All contaminated subcutaneous fat and devitalized muscle must be removed. Bone without soft tissue attachments should be excised. Elimination of dead space is vital. Wound closure is to be avoided due to a significant chance of infection. The associated fractures should be stabilized by external or internal fixation. Secondary wound closure can usually be performed within 1-2 weeks after injury. We used

X- Ray and CT scanning liberally, however MRI would have been the most desirable. It was not possible to use it due to obvious reasons.

Two aspects of crowd control were found to have an effect on the management of these wounds. The gun per se does not have a significant research back up [7]. Without the research back up, the standard operating protocol about the use of these guns is difficult to guess. We, however observed that shots fired from a distance did not cause deep extraocular damage. According to the patients who had been shot at point blank range or from very short distances, the damage was significant. The severity of the injury in inverse proportion to the distance from which the gun was fired probably suggests that lethality is proportional to the intent of the shooter. It is pertinent to mention here that the Indian police and paramilitaries are signatory to the Geneva Convention, but the 'heat of the moment' may introduce dangerous uncertainties in the use of this gun. The amnesty international has reported that "In dozens of countries around the world, we've documented how police have misused and abused tear gas, rubber bullets and electric shock equipment, amongst many other dangerous devices, to quell protests [8].In several situations, the goal of incapacitating an individual is not achieved whilst producing internal organ damage [2]

There is a lot of literature which supports the renaming of kinetic energy based munitions as lethal weapons. Recent research even focuses of non-projectile weapons stating that each type of non-projectile less lethal weapon also has a number of physiologic effects and specific medical issues that must be considered when the weapon is used. [9, 10, $11,12,13,14]$ There is no clear evidence, yet that the non-projectile devices are inherently lethal, nor is there good evidence to suggest a causal link between sudden in-custody death and the use of irritant sprays or conducted energy devices $[15,16]$

Users of less lethal kinetic impact munitions are trained to target the torso and proximal extremities of a suspect while avoiding the head, neck, precordium and groin areas. However, the relatively poor aerodynamics of these large surface area projectiles makes these weapons fairly inaccurate [3].

\section{Conclusion:-}

Real efforts must now be made to identify or develop acceptable non-lethal (or less than-lethal) weapons. Better training of the police and the paramilitaries is also necessary so that acceptable damage is caused while crowds are being restrained. It is also important for surgeons to be fully trained in the management of ballistic wounds. In extension, there should be dissemination of literature concerning newer projectile munitions so that doctors are able to at work along some basic guidelines to improve patient care. 


\section{Bibliography:-}

1. Muller RA. Less Lethal Weapons. Are they honorable or horrible? We don't yet know-but they might give us valuable options in Iraq and elsewhere.

2. Kobayashi M, Mellen PF. Rubber Bullet Injury Case Report With Autopsy Observation and Literature Review. Am J Forensic Med Pathol 2009;30: 262-267.
3. Hamdorf
Non
lethal
incapacitation http://www.aic.gov.au/media_library/publications/proceedings/18/hamdorf2.pdf

4. Bozeman W, Winslow J. Medical Aspects of Less Lethal Weapons. The Internet Journal of Rescue and Disaster Medicine. 2004 Volume 5 Number 1.

5. Dhar SA, Dar TA, Wani SA. Pattern of rubber bullet injuries in the lower limbs: A report from Kashmir. http://dx.doi.org/10.1016/j.cjtee.2015.05.005

6. McKay T. "Nonlethal" Weapons Are Much More Lethal Than Police Want You to Think Policy Mic August 05, 2015

7. Ahsan S. Pellets generally used in hunting animals: Gun manufacturer. Indian Express September 7, 2016

8. Marczynski M. 'Less-lethal' weapons can kill and police misuse them for torture. Amnest International 13 April 2015, 00:01 UTC.

9. Millar R, Rutherford WH, Johnston S, et al. Injuries caused by rubber bullets: a report on 90 patients. Br J Surg. 1975;62:480e486.

10. Rocke L. Injuries caused by plastic bullets compared with those caused by rubber bullets. Lancet. 1983;1:919e920.

11. Rezende-Neto J, Silva FD, Porto LB, et al. Penetrating injury to the chest by an attenuated energy projectile: a case report and literature review of

12. thoracic injuries caused by "less-lethal" munitions. World J Emerg Surg. 2009;4:26.

13. Khonsari RH, Fleuridas G, Arzul L, et al. Severe facial rubber bullet injuries: less lethal but extremely harmful weapons. Injury. 2010;41:73e76.

14. Lavy T, Asleh SA. Ocular rubber bullet injuries. Eye (Lond). 2003;17:821e824.

15. Vilke MG, Chan TC. Less lethal technology; medical issues.Policing An International Journal of Police Strategies and Management 30(3):341-357 . August 2007

16. Kenny, J., Heal, S, Grossman, M, The Attribute-Based Evaluation(ABE) of Less-Than-Lethal, Extended-Range, Impact Munitions. 2001, National Institute of Justice ; The Pennsylvania State University Applied Research Laboratory; The Los Angeles Sheriff's Department. 